\title{
ОЦЕНКА ОЖИДАЕМОЙ ТОЧНОСТИ СТРУКТУРНЫХ ПОСТРОЕНИЙ ПРИ НВСП
}

Ленский В.А., Адиев Р.Я., Сергеев А.А.

(ОАО НПЦЦ «Геостра»)

Выделены основные причины ошибок и предложена оценка ожидаемой точности структурных построений по данным НВСП. Достоверность оценки рассмотрена на примере практического расхождения данньх бурения и ВСП на хорошо разбуренном объекте.

Общепринятая методика оценки ожидаемой точности структурных построений в НВСП пока отсутствует, что создает определенные проблемы в общении с заказчиками работ.

Влияние изменения строения ВЧР на структурные построения по данным НВСП незначительно, основные причины ошибок следующие.

1. Погрешность снятия времен (глубин) при корреляции отражений. Для уверенно прослеживаемых отражений она, очевидно, определяется половиной произведения шага дискретизации на скорость. Для слабых отражений погрешность резко увеличивается из-за влияния случайных факторов интерференции с другими волнами.

2. Наличие горизонтальной анизотропии скорости. Современное программное обеспечение позволяет получить количественную оценку горизонтальной анизотропии скорости (по сопоставлению времен первых вступлений при продольном ВСП и при НВСП) и уменьшить ее влияние до уровня первой рассмотренной причины.

3. Ошибки данных инклинометрии, которые могут достигать многих десятков метров и вызывать ошибки структурных построений в несколько десятков метров. Характерным признаком зтих ошибок является возрастающее с удалением от скважины завышение глубин в каком либо одном направлении (из-за завышения удаления источника от ствола скважины) и занижение глубин в противоположном направлении.

4. Шероховатость отражающей границы. Поверхность карбонатных пород на контакте с покрывающими терригенными часто изрезана водной эрозией, колебание глубин может достигать \pm 2 м и более при горизонтальных размерах неоднородностей первые метры.

5. Наличие локальных скоростных неоднородностей в средней части разреза. Отпичить их влияние от изменения строения нижележащих горизонтов трудно, но иногда удается по характерному приближению аномального участка к скважине с увеличением глубины отражений. Сушественную помощь оказывает совместное рассмотрение разрезов в монотипньг и обменных волнах или применение перекрестных наблюдений.

6. Наличие локальных (менее половины размеров зоны Френеля) эрозионных врезов и выступов, сейсмические изображения которых вследствие дифракции волн искажаются или даже совсем не проявляются в волновом поле.

7. Боковой снос отражений на крутом склоне. Проявляется в уменьшении глубин.
8. Рефракция волн в средах с большим вертикальным градиентом скорости. Приводит к завышению глубин, возрастающему с удалением трассы разреза от скважины по зависимости, близкой к параболической. Влияние рефракции устраняется применением алгоритмов обработки, учитывающих вертикальный градиент скорости.

Три первые причины (погрешности снятия времен или глубин, горизонтальная анизотропия скорости, погрешности инклинометрии) присутствуют всегда, причем погрешности инклинометрии в новых скважинах обынно достаточно умеренные и их влияние соизмеримо с двумя другими причинами. Поэтому влияние всех трех причин можно принять равным и для уверенно прослеживаемьг отражений ожидаемую точность структурных построений $\sigma_{\mathrm{h}}$ для гладких границ (кровля терригенных пород и прослои в них) оценить выражением $\sigma_{\mathrm{h}}= \pm \sqrt{3} \Delta \mathrm{t} \cdot \mathrm{V} / 2$, где $\Delta \mathrm{t}-$ war дискретизации записи, $\mathrm{V}$ - скорость упругих волн. При $\Delta \mathrm{t}=1 \mathrm{мc}$ ожидаемая точность структурных построений по продольньм волнам составит $\pm(3-5)$ м. Для шероховатой границы ошибки структурных построений возрастут за счет случайного попадания скважин на мелкую морфологическую неровность поверхности, ожидаемая точность структурных построений составит $\pm(5-7)$ M.

Значительные опибки инклинометрии, локальные скоростные неоднородностей в средней части разреза, локальные эрозионных врезы и выступы на отражающей поверхности, боковой снос встречаются реже и носят случайный характер, но именно они приводят к большим расхождениям данных ВСП и бурения (до \pm 20 м и более).

Достоверность приведенных оценок подтверждается анализом практического расхождения данных бурения и ВСП. Рассмотрен пример расхождения данных бурения и ВСП на участке, где в области прослеживания по ВСП находится 11 пробуренныт скважин. Этот пример интересен наличием широкого набора причин ошибок. Определение расхождения данных ВСП выполнено путем экспертной корреляции отражений и сравнения результатов с бурением. Причиной появления повышенных расхождений (до $8 \mathrm{~m}$ ) явились шероховатость кровли ангидритов окского горизонта и боковой снос на крутом склоне, а больших расхождений (до 22 м) - ошибки инклинометрии. В остальном среднеквадратицеская величина расхождений для разных отражающих горизонтов составила $\pm(2-5)$ м, что находится в диапазоне приведенныг оценок. 